\title{
TOTAL RESPIRATORY SUPPORT FROM SWINE LUNGS IN PRIMATE RECIPIENTS
}

C. William Daggett, $\mathrm{MD}^{\mathrm{a}}$

Mark Yeatman, FRCS ${ }^{\mathrm{a}}$

Andrew J. Lodge, MD ${ }^{\mathrm{a}}$

Edward P. Chen, MD

Shu S. Linn, MD

Carmelo Gullotto, $\mathrm{BBA}^{\mathrm{a}}$

Michael M. Frank, MD ${ }^{\mathrm{b}}$

Jeffrey L. Platt, MD ${ }^{\mathrm{a}, \mathrm{b}}$

R. Duane Davis, MD

Sponsor:

Ross M. Ungerleider, MD
The use of nonhuman lung donors, such as swine, has the potential to provide an unlimited supply of organs. However, hyperacute rejection has prevented pulmonary xenotransplantation. Objective: Our aim was to test the hypothesis that immunodepletion by pretransplantation swine lung perfusion will prevent hyperacute swine-to-primate pulmonary xenograft rejection and allow for a functional swine pulmonary xenograft. Methods: Seven baboons underwent left pneumonectomy followed by orthotopic transplantation of the swine left lung. Four baboons received immunodepletion by perfusion with swine lungs before transplantation, and three received no treatment before transplantation. Results: After transplantation, pulmonary xenografts from immunodepleted baboons had a low pulmonary vascular resistance and a high pulmonary blood flow compared with control animals, which had a high pulmonary vascular resistance and a low pulmonary blood flow. After 60 minutes of reperfusion, three of four immunodepleted animals also tolerated complete occlusion of the right pulmonary artery, with the baboon relying completely on the swine pulmonary xenograft for respiratory function for 11 hours. Pathologic analysis of peripheral lung biopsy specimens taken from control lungs displayed alveolar disruption and hemorrhage within small vessels, whereas swine lungs transplanted into immunodepleted baboons displayed little histologic evidence of injury. Furthermore, pulmonary xenografts transplanted into immunodepleted baboons demonstrated excellent respiratory function and adequate hemodynamics during occlusion of the right pulmonary artery. Conclusion: Hyperacute pulmonary xenograft rejection can be prevented by pretransplantation swine lung perfusion. Swine pulmonary xenografts can provide complete respiratory support in primates when rejection is prevented. (J Thorac Cardiovasc Surg 1998;115:19-27)
$\Lambda \mathrm{s}$ pulmonary transplantation has become sucAcessful, the number of patients on the waiting list far exceeds the supply of cadaveric donors. ${ }^{1}$

From the Departments of Surgery, ${ }^{\mathrm{a}}$ Pediatrics and Immunology, Medical Science Research Building, Box 2605, Duke University Medical Center, Durham, N.C.

Supported by National Institutes of Health grants HL50985 and HL52297.

Read at the Seventy-seventh Annual Meeting of The American Association for Thoracic Surgery, Washington, D.C., May 4-7, 1997.

Received for publication May 7, 1997; revisions requested July 11, 1997; revisions received Sept. 5, 1997; accepted for publication Sept. 8, 1997.

Address for reprints: R. Duane Davis, MD, Assistant Professor of Surgery, Director of Cardiopulmonary Transplantation, Duke University Medical Center, DUMC 3864, Durham, NC 27710.

Copyright (C) 1998 by Mosby, Inc.

$0022-5223 / 98 \$ 5.00+0 \quad \mathbf{1 2 / 6 / 8 5 9 9 8}$
The supply of cadaveric donors remains relatively constant while the number of patients on the waiting list is rapidly growing. ${ }^{1,2}$ Although mechanical devices have been developed that can assume the function of organs, such as the kidney and heart, no suitable mechanical replacement for the lungs is available. ${ }^{3}$ Thus an alternative source of pulmonary donors must be developed if the field of pulmonary transplantation is to fulfill its goal for all patients.

Successful pulmonary replacement has four major requirements. First, the organ must be of proper size to fit within the thoracic cavity and achieve proper anastomosis. Second, it must be able to oxygenate hemoglobin and remove carbon dioxide sufficiently to maintain respiratory equilibrium. Third, resistance to flow through the graft must be low enough to sustain cardiac output and right ventricular function. Finally, the organ must be 


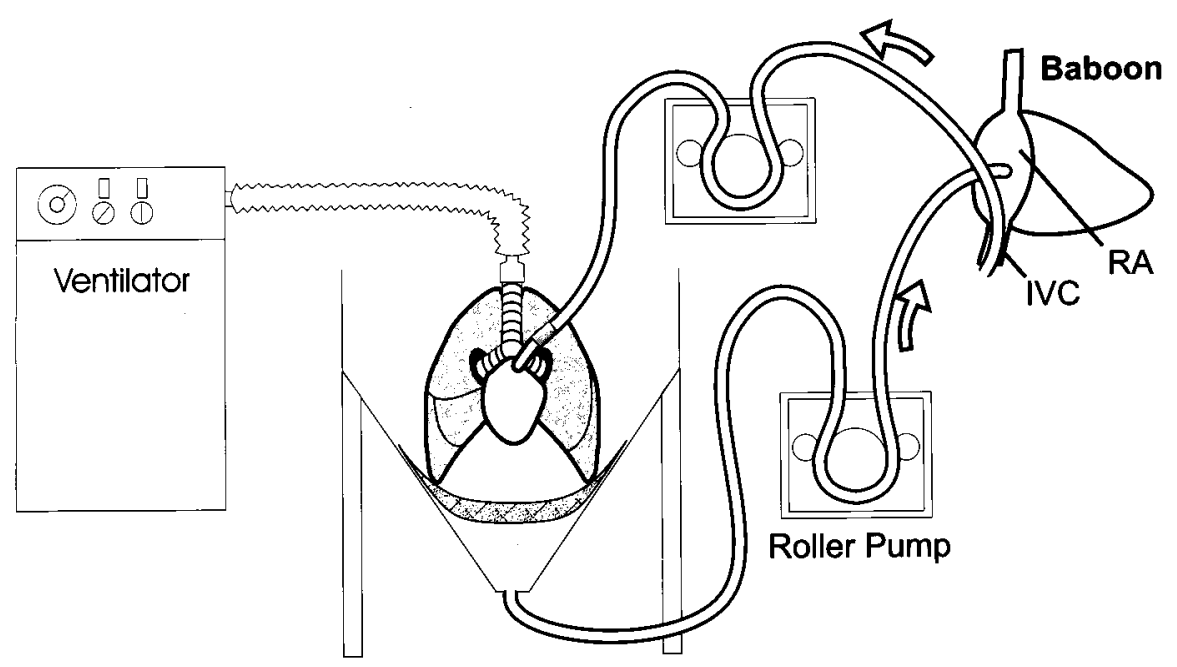

Fig. 1. Diagram of extracorporeal perfusion circuit. Blood is removed from the baboon inferior vena cava and delivered to the swine main pulmonary artery with a roller pump. Blood is drained into a reservoir and returned to the baboon with a second roller pump. The lungs are ventilated with an inspired oxygen fraction of 0.6 , and the peak inspiratory pressure is maintained between 25 to $30 \mathrm{~cm} \mathrm{H}_{2} \mathrm{O}$ during the procedure. $I V C$, Inferior vena cava; $R A$, right atrium.

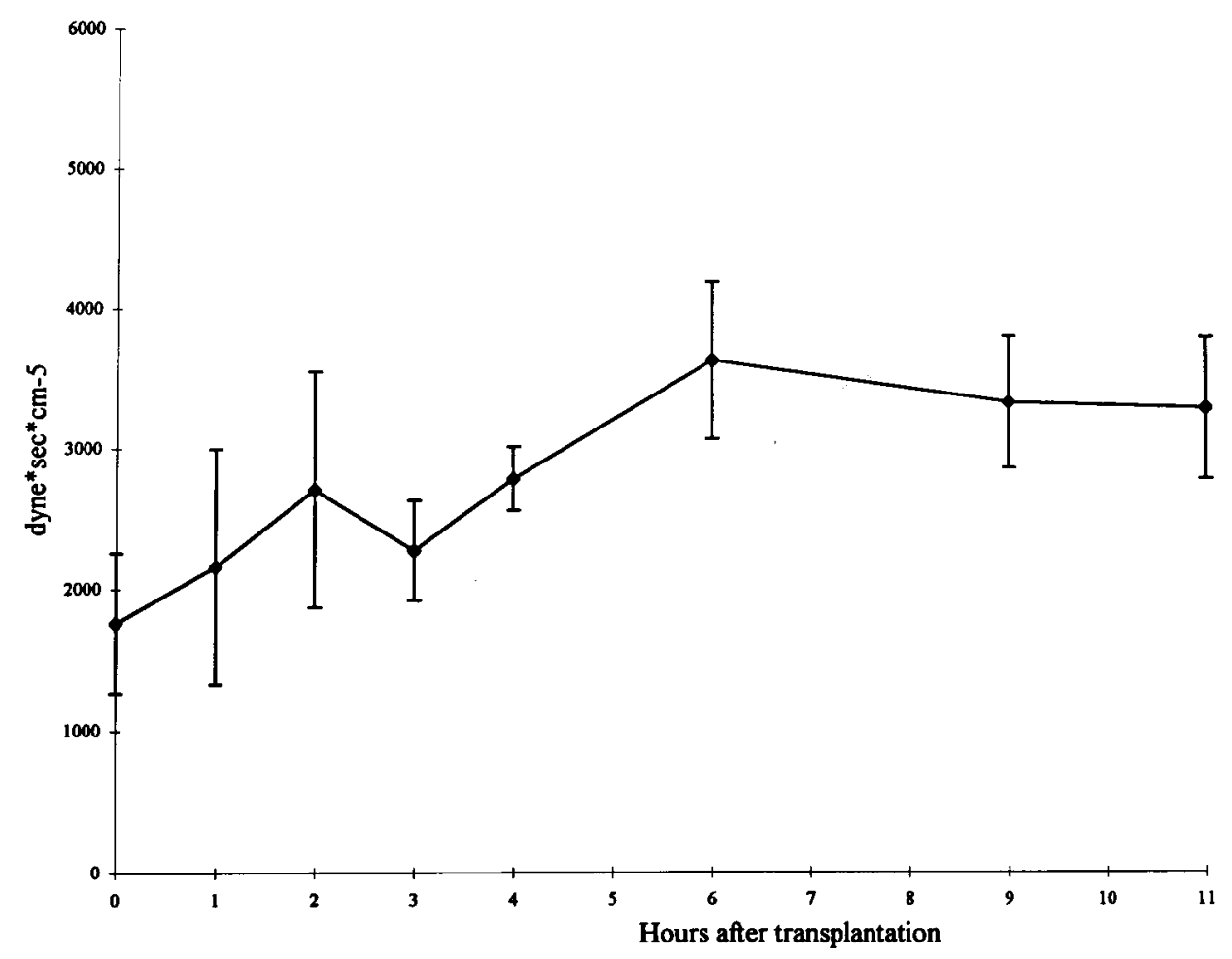

Fig. 2. PVR of immunodepleted baboons before transplantation and after transplantation with the right pulmonary artery occluded at 1 hour.

durable enough to justify the undertaking of the pulmonary transplantation procedure.

The use of discordant species, such as swine, as a source of pulmonary replacements could provide enough organs to meet the growing need for pulmonary donors but, thus far, has not been feasible because of the failure of pulmonary xenografts to maintain any significant blood flow. ${ }^{4-6}$ Recent inves- 


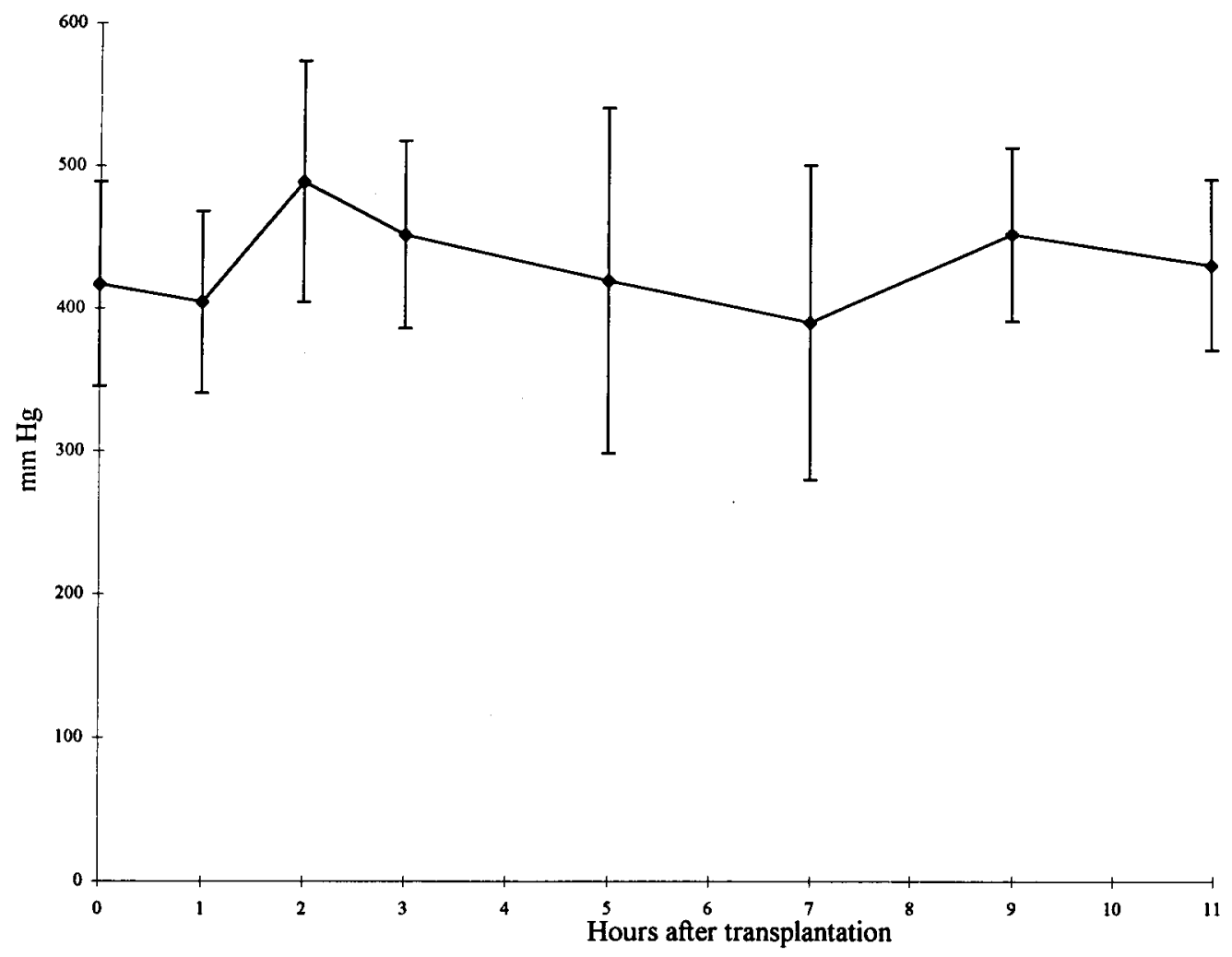

Fig. 3. Arterial oxygen tension. Oxygenation of immunodepleted baboons before transplantation and after transplantation with the right pulmonary artery occluded at 1 hour.

tigation of the mechanisms underlying swine-toprimate pulmonary xenograft dysfunction have established that the complement system is intricately involved in this process. ${ }^{7}$ Lungs from genetically engineered swine expressing human complement regulatory proteins have also demonstrated prolonged function in primate recipients. ${ }^{8}$ The goal of this short-term study is to determine whether swineto-primate pulmonary xenograft rejection can be prevented by pretransplantation immunodepletion and to determine whether swine lungs can be used for successful orthotopic pulmonary replacements in primate recipients.

\section{Materials and methods}

Recipient preparation. Seven adult baboons (Papio anubis), which had previously demonstrated the ability to reject a swine cardiac transplant, were premedicated with ketamine hydrochloride $\left(10 \mathrm{mg} \cdot \mathrm{kg}^{-1}\right)$ and glycopyrrolate (INN: glycopyrronium bromide) $\left(0.1 \mathrm{mg} \cdot \mathrm{kg}^{-1}\right)$. Anesthesia was introduced with sodium thiopental $\left(2 \mathrm{mg} \cdot \mathrm{kg}^{-1}\right)$ and maintained with a fentanyl drip $\left(20 \mu \mathrm{g} \mathrm{kg}{ }^{-1} \cdot \mathrm{min}^{-1}\right)$. Neuromuscular blockade was achieved with intravenous succinylcholine $\left(0.1 \mathrm{mg} \cdot \mathrm{kg}^{-1}\right)$. All animals were intubated and their lungs ventilated with an adult volume-controlled ventilator (Bennett Respiration Products, Inc., Santa
Monica, Calif.). Baboons were given conventional triple immunosuppressive therapy consisting of cyclosporine (INN: ciclosporin) $\left(15 \mathrm{mg} \cdot \mathrm{kg}^{-1}\right)$, azathioprine $\left(2 \mathrm{mg} \cdot \mathrm{kg}^{-1}\right)$, and methylprednisolone $\left(8 \mathrm{mg} \cdot \mathrm{kg}^{-1}\right) 2$ hours before transplantation. Heparin $\left(1000 \mathrm{U} \cdot \mathrm{kg}^{-1}\right)$ was administered 5 minutes before perfusion in immunodepleted baboons and 5 minutes before transplantation in control animals. Control baboons underwent a left posterolateral thoracotomy and immunodepleted baboons underwent a bilateral thoracotomy. Arterial pressure and blood gases were monitored by cannulation of the right femoral artery. An ultrasonic flow probe was placed on the main pulmonary artery and left pulmonary artery, and micromanometers (Millar Instruments, Inc., Houston, Tex.) were placed in the pulmonary artery and left atrium. All animals received humane care in compliance with the "Guide for the Care and Use of Laboratory Animals" published by the National Institutes of Health (NIH publication 85-23, revised 1985).

Donor operation. Domestic swine (15 to $20 \mathrm{~kg}$ ) were obtained from Walnut Hill Farms, Hillsborough, North Carolina. Animals were anesthetized with intramuscular administration of ketamine hydrochloride $\left(20 \mathrm{mg} \cdot \mathrm{kg}^{-1}\right)$ and intravenous fentanyl $\left(100 \mu \mathrm{g} \cdot \mathrm{kg}^{-1}\right)$. Endotracheal intubation and ventilation were established with $100 \%$ oxygen. All swine received methylprednisolone $\left(8 \mathrm{mg} \cdot \mathrm{kg}^{-1}\right)$ and indomethacin (INN: indometacin) $\left(1 \mathrm{mg} \cdot \mathrm{kg}^{-1}\right) 1$ hour before harvest. A median sternotomy was performed. Alprostadil (prostaglandin $\left.\mathrm{E}_{1}\right)\left(50 \mu \mathrm{g} \cdot \mathrm{kg}^{-1}\right)$ was injected 


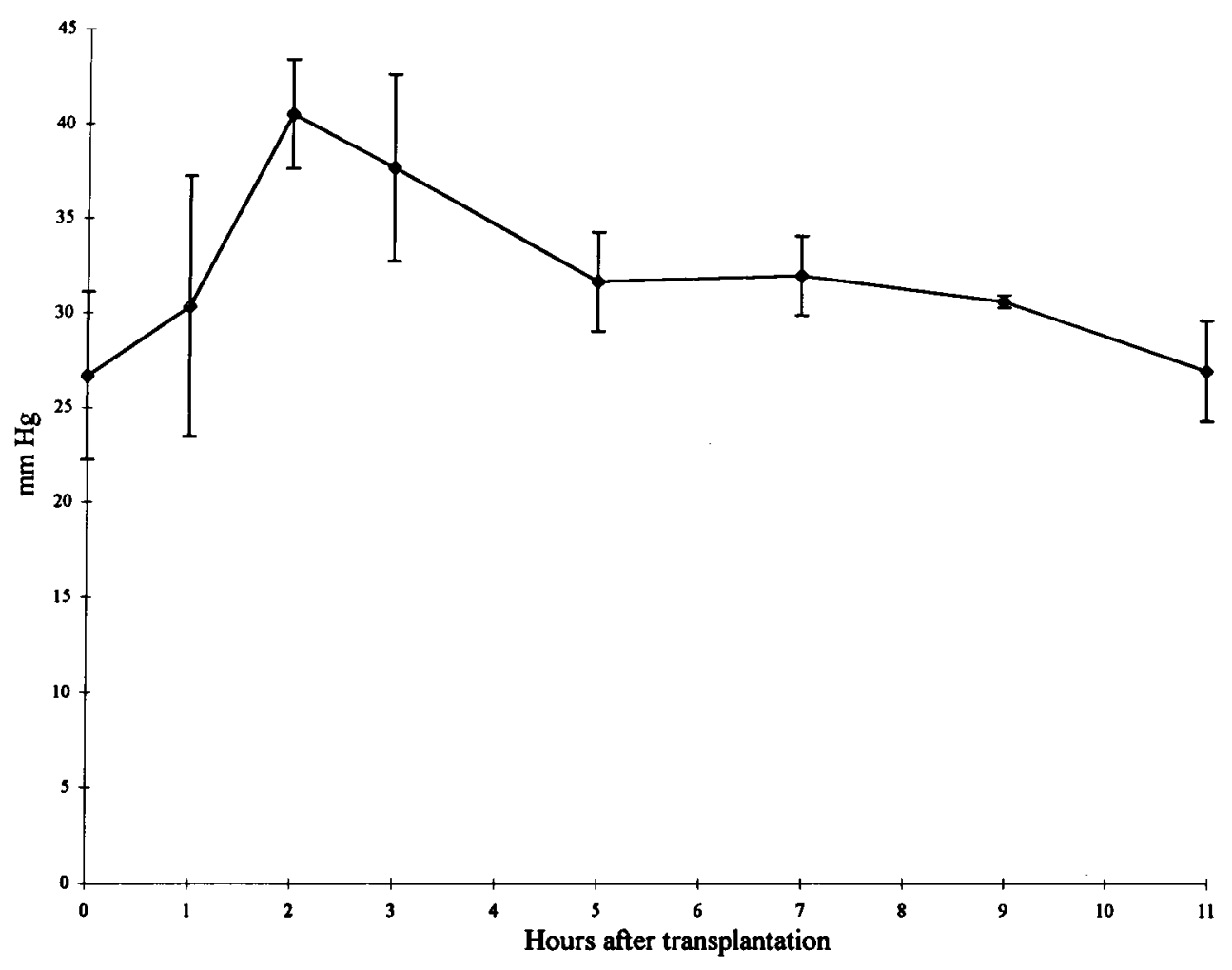

Fig. 4. Arterial carbon dioxide tension. Ventilation of immunodepleted baboons before transplantation and after transplantation with the right pulmonary artery occluded at 1 hour.

directly into the pulmonary artery and heparin was administered intravenously $\left(500 \mathrm{U} \cdot \mathrm{kg}^{-1}\right) 10$ minutes before harvest. The venae cavae were ligated and the left and right atria were incised to allow for venting during the preservation process. "Duke Blue Solution \#1" (25 ml $\mathrm{kg}^{-1}$ ), consisting of Euro-Collins solution containing heparin $\left(10 \mathrm{U} \cdot \mathrm{ml}^{-1}\right)$, papaverine hydrochloride $(0.1 \mathrm{mg} \cdot$ $\left.\mathrm{ml}^{-1}\right)$, methylprednisolone $\left(1 \mathrm{mg} \cdot \mathrm{ml}^{-1}\right)$, indomethacin $\left(0.1 \mathrm{mg} \cdot \mathrm{ml}^{-1}\right)$, and nicardipine $\left(0.2 \mathrm{mg} \cdot \mathrm{ml}^{-1}\right)$ (Wyeth Laboratories Inc. Philadelphia, Pa.), was administered into the main pulmonary artery from a height of $30 \mathrm{~cm}$. The heart and lungs were removed en bloc and immersed in cold $\left(4^{\circ} \mathrm{C}\right)$ saline solution. The total ischemic time in both groups was consistently less than 55 minutes.

Pretransplantation extracorporeal pulmonary perfusion. Immunodepleted baboons had a $20 \mathrm{~F}$ venous cannula inserted into the right atrial appendage and an $18 \mathrm{~F}$ right-angled cannula placed in the inferior vena cava. The extracorporeal circuit was constructed as shown in Fig. 1. Swine lungs were harvested from adult animals as described earlier. The heart-lung block was ventilated with an adult volume-controlled respirator, with tidal volume adjusted to maintain the peak airway pressure at $35 \mathrm{~cm}$ $\mathrm{H}_{2} \mathrm{O}$. Blood was drawn from the baboon inferior vena cava through standard polyvinylchloride tubing with a roller pump (Sarns Inc., Ann Arbor, Mich.) to the main pulmonary artery of the swine lungs and allowed to drain into a stainless steel reservoir via a cannula in the porcine left ventricle. The blood in the reservoir was recirculated to the baboon right atrium with a second roller pump. A $40 \mu \mathrm{m}$ filter with an air trap was placed in the return circuit to prevent air and debris from entering the baboon. A heat exchanger (Medtronic Cardiopulmonary, Anaheim, Calif.) was incorporated to maintain the temperature of the reservoir at $37^{\circ} \mathrm{C}$. The circuit was primed with "Duke Blue Solution \#2," consisting of lactated Ringer's solution $(500 \mathrm{ml})$ with the addition of mannitol (40 gm), calcium $(25 \mathrm{mEq})$, magnesium sulfate $(2 \mathrm{gm})$, epinephrine chloride (Adrenaline, $1 \mathrm{mg}$ ), and furosemide (Lasix, $10 \mathrm{mg}$ ). Perfusion was begun at a rate of $100 \mathrm{ml} \cdot \mathrm{min}^{-1}$, and once the baboon was hemodynamically stable the rate was increased to $250 \mathrm{ml} \cdot \mathrm{min}^{-1}$ for a total of 120 minutes. The porcine pulmonary artery pressure was monitored with an in-line microtransducer in the proximal pulmonary artery, and the porcine pulmonary blood flow was confirmed with in-line ultrasonic flowmeters. Prime solution was added to the circuit as needed to maintain a reservoir volume of $250 \mathrm{ml}$.

Recipient operation. All baboons underwent left pneumonectomy followed by left orthotopic swine lung transplantation. Four baboons received immunodepletion by perfusion with swine lungs before transplantation. Three baboons received no treatment before transplantation. Pulmonary transplantation was achieved with anastomosis 


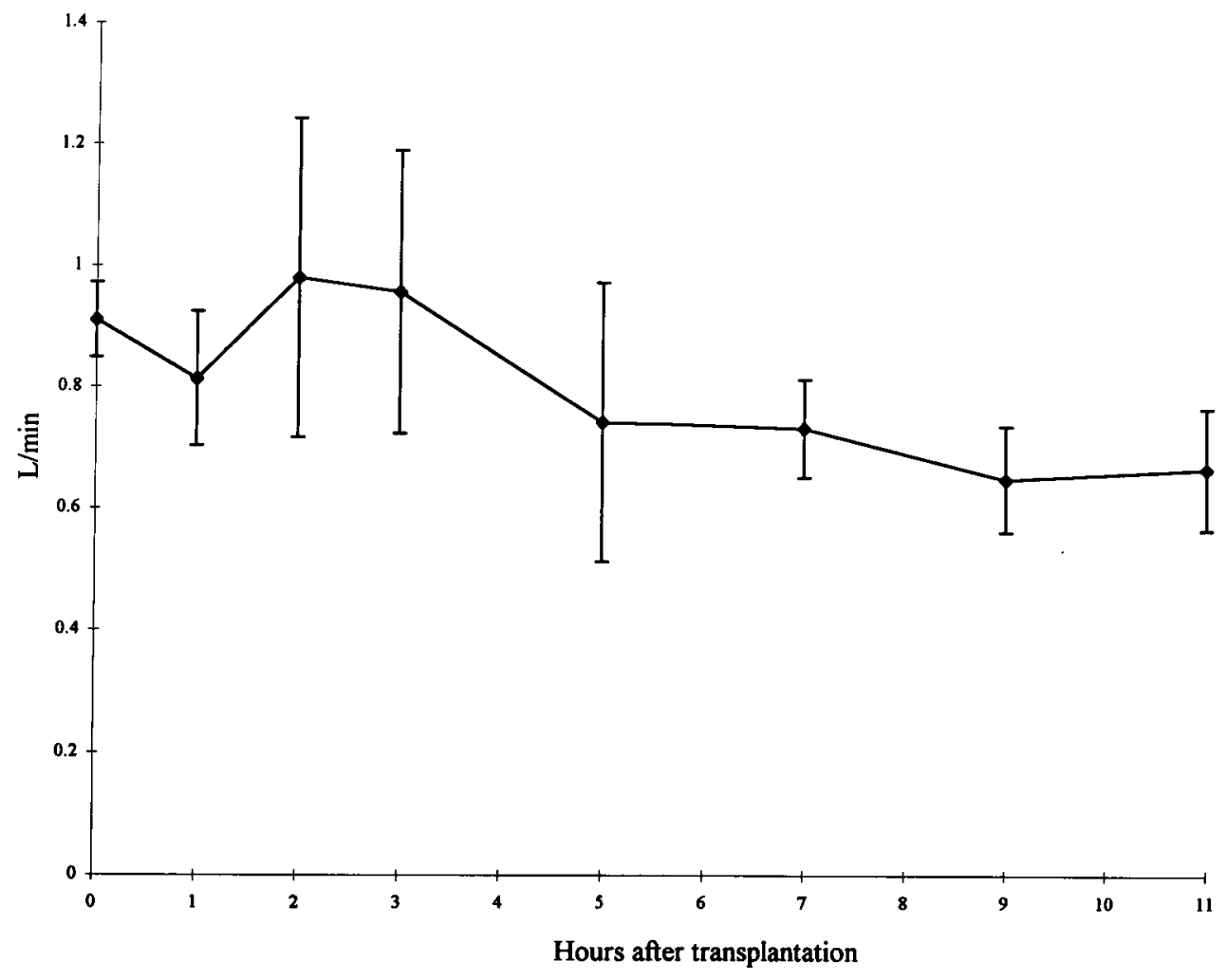

Fig. 5. Cardiac output of immunodepleted baboons before transplantation and after transplantation with the pulmonary artery occluded at 1 hour.

of the left bronchus, pulmonary veins, and pulmonary artery with the use of continuous 4-0, 5-0, and 6-0 monofilament sutures, respectively.

Statistical analysis. Changes in indices of pulmonary vascular resistance (PVR) were examined by a two-way analysis of variance test with the use of a standard statistical software program (Microsoft Corp., Seattle, Wash.). Results are presented as the mean \pm standard error of the mean. Values of $p<0.05$ were considered to be statistically significant.

Measurement of xenoreactive antibody. The levels of the baboon xenoreactive antibody anti-galactose $\alpha(1,3)$ galactosyl immunoglobulin $\mathrm{M}$ (anti-Gal $\alpha[1,3] \mathrm{Gal}$ IgM) were measured with the use of a porcine aortic endothelial enzyme-linked immunosorbent assay as described previously. ${ }^{9}$

Measurement of total complement assay. The levels of complement in baboons were determined with the use of a sheep red blood cell lysis assay as described previously. ${ }^{10}$

\section{Results}

Pulmonary perfusion. Pretransplantation perfusion of baboons was well tolerated. One hundred twenty minutes of perfusion with swine lungs achieved an $81.8 \%$ reduction in the plasma levels of
anti-Gal $\alpha(1,3) \mathrm{Gal} \operatorname{IgM}\left(37.3\right.$ to $\left.6.8 \mu \mathrm{g} \cdot \mathrm{ml}^{-1}\right)$, an $84.6 \%$ reduction in the white blood cell count (13 to $2 \cdot 10^{3} \mathrm{ml}^{-1}$ ), and a $94.9 \%$ reduction in the platelet count (455 to $23 \cdot 10^{3} \mathrm{ml}^{-1}$ ). The total complement assay was $10.5 \mathrm{U} \cdot \mathrm{ml}^{-1}$ before perfusion and 11.2 $\mathrm{U} \cdot \mathrm{ml}^{-1}$ at the end of perfusion.

Pulmonary hemodynamics. After transplantation, lungs transplanted into immunodepleted baboons had a blood flow of $813.3 \pm 110.5 \mathrm{ml} \cdot \mathrm{min}^{-1}$ and a PVR of $1668 \pm 834 \mathrm{dyne} \cdot \mathrm{sec} \cdot \mathrm{cm}^{-5}$ at 60 minutes of reperfusion; by contrast, control animals had a pulmonary blood flow of $26.7 \pm 12.1 \mathrm{ml}$. $\min ^{-1}(p=0.019)$ and a PVR of 35,232 $\pm 15,688$ dyne $\cdot \mathrm{sec} \cdot \mathrm{cm}^{-5}(p=0.049)$. At 3 hours after transplantation the pulmonary xenograft blood flow diminished to $13.3 \pm 3.0 \mathrm{ml} \cdot \mathrm{min}^{-1}$ in control animals with a PVR of $72,000 \pm 2,480 \mathrm{dyne} \cdot \mathrm{sec} \cdot \mathrm{cm}^{-5}$, whereas immunodepleted baboons continued to have pulmonary xenograft function for the duration of the 11-hour study (Fig. 2). Furthermore, after 60 minutes of reperfusion, three of four immunodepleted animals tolerated complete occlusion of the right 


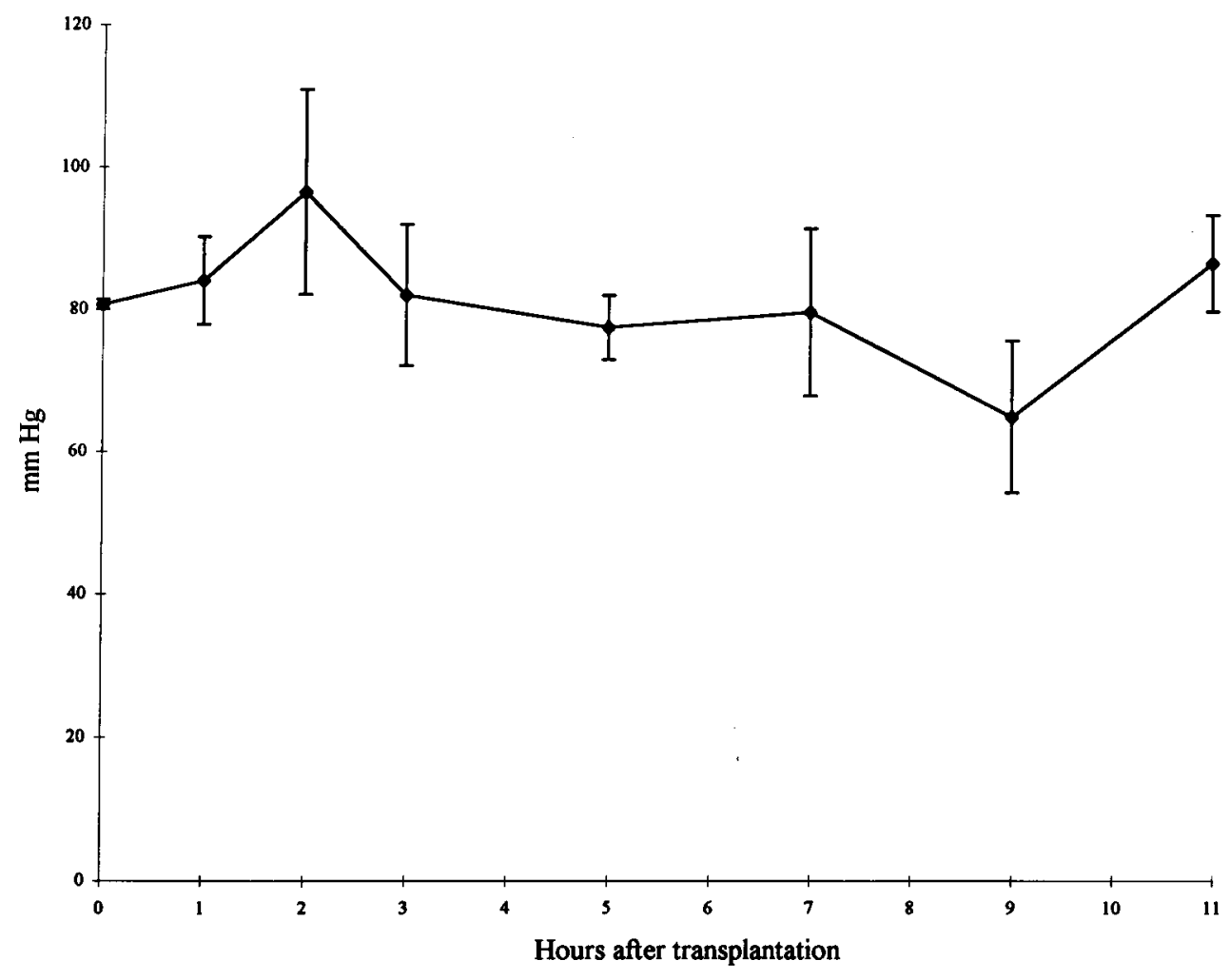

Fig. 6. Systolic blood pressure of immunodepleted baboons before transplantation and after transplantation with the right pulmonary artery occluded at 1 hour.

pulmonary artery, with the baboon relying completely on the swine pulmonary xenograft for respiratory function for the remainder of the study. At 11 hours of reperfusion immunodepleted baboons had a pulmonary blood flow of $433.3 \pm 24.2 \mathrm{ml} \cdot \mathrm{min}^{-1}$ with a PVR of $3048 \pm 1524 \mathrm{dyne} \cdot \mathrm{sec} \cdot \mathrm{cm}^{-5}$. The three control animals did not tolerate occlusion of the right pulmonary artery and had cardiovascular failure within 20 seconds of occlusion.

Respiratory function. While relying on the transplanted swine lung, immunodepleted baboons were maintained at an inspired oxygen fraction of 1.0 and a minute ventilation of $3900 \pm 260 \mathrm{ml} \cdot \mathrm{min}^{-1}$. Arterial blood gas analysis demonstrated an oxygen tension of $417.0 \pm 71.8 \mathrm{~mm} \mathrm{Hg}$ at baseline, $404.3 \pm$ $63.8 \mathrm{~mm} \mathrm{Hg}$ at 1 hour, and $431.7 \pm 60.2 \mathrm{~mm} \mathrm{Hg}$ at 11 hours of reperfusion (Fig. 3). The carbon dioxide tension was $26.7 \pm 4.4 \mathrm{~mm} \mathrm{Hg}$ at baseline, $30.3 \pm$ $6.9 \mathrm{~mm} \mathrm{Hg}$ at 1 hour, and $27.0 \pm 2.7 \mathrm{~mm} \mathrm{Hg}$ at 11 hours after reperfusion (Fig. 4).

Baboon hemodynamics. The baboons in the immunodepleted group were hemodynamically stable without inotropic support while the right pulmonary artery was occluded. As shown in Fig. 5, the baseline cardiac output was $910 \pm 60 \mathrm{ml} \cdot \mathrm{min}^{-1}, 810 \pm$ $110 \mathrm{ml} \cdot \mathrm{min}^{-1}$ at 1 hour of reperfusion, and $670 \pm$ $100 \mathrm{ml} \cdot \mathrm{min}^{-1}$ at 11 hours of reperfusion. The systolic arterial blood pressure was also well maintained with a baseline value of $80.7 \pm 0.67 \mathrm{~mm} \mathrm{Hg}$, $84.0 \pm 6.1 \mathrm{~mm} \mathrm{Hg}$ at 1 hour, and $86.7 \pm 6.8 \mathrm{~mm} \mathrm{Hg}$ at 11 hours of reperfusion (Fig. 6).

Histology. Pathologic analysis of peripheral lung biopsy specimens taken from control animals at 1 hour of reperfusion showed alveolar disruption and hemorrhage, with small-vessel thrombosis progressing to large-vessel thrombosis and alveolar consolidation at 3 hours. Lungs from immunodepleted baboons displayed little histologic evidence of injury in biopsy tissue taken at 1,3 , and 11 hours of reperfusion (Fig. 7).

\section{Discussion}

This study demonstrates that swine lungs transplanted into immunodepleted baboons are capable of providing total respiratory support. They meet the criteria for appropriate anatomic size and ability 

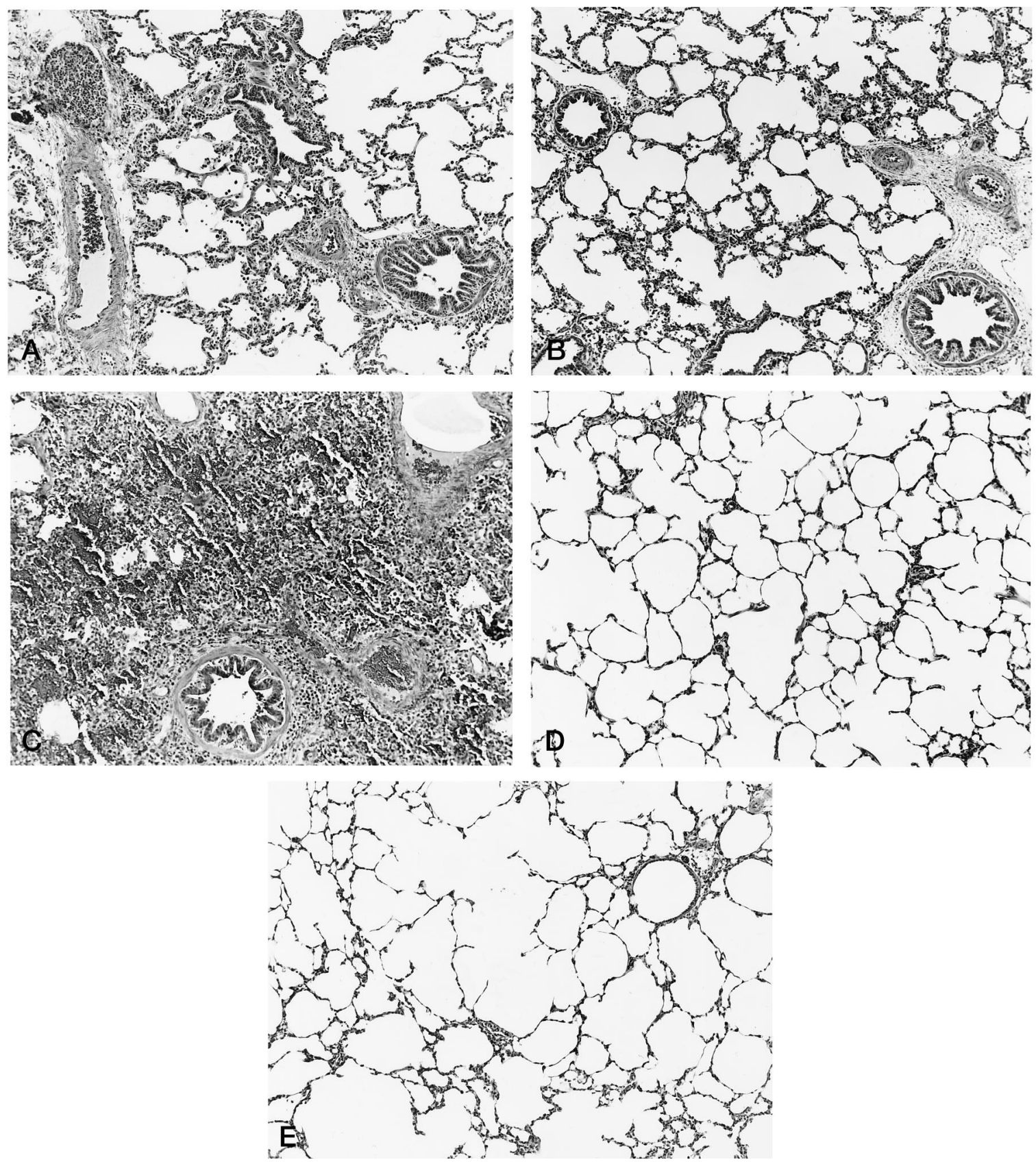

Fig. 7. Light micrographs (hematoxylin and eosin stain) of porcine pulmonary xenografts at 1 hour after transplantation in control baboons (A) and immunodepleted baboons (B) and at 3 hours after transplantation in control (C) and immunodepleted baboons (D). Eleven-hour micrograph of a pulmonary xenograft transplanted into an immunodepleted baboon (E).

to provide gas exchange, and they have a sufficiently low vascular resistance to prevent right ventricular failure. However, the durability of swine lung xenografts has not been fully tested. Survival studies are warranted to determine the clinical, physiologic, and immunologic course of the functional swine pulmonary xenograft.

Although pretransplantation swine lung perfusion has been proved to prevent swine-to-primate pulmonary xenograft rejection, the exact mecha- 
nisms responsible for this effect have not been fully elucidated. Although xenoreactive antibodies were depleted, other blood elements, both measured and unmeasured, were surely removed. Red blood cells, white blood cells, and platelets were all found to be diminished. Although coagulation factors were not measured, dense fibrin deposition in perfused lungs suggests that these elements were also decreased after lung perfusion. Thus, although the antibodydependent classic complement pathway may appear to play a role in swine-to-primate pulmonary xenograft rejection, ${ }^{7,8}$ the efficacy of pretransplantation lung perfusion may, in fact, reflect diverse mechanisms by which rejection is prevented.

The baboons in this preliminary investigation were previously used in studies of swine heart xenograft rejection. The average length of time from the heart transplantation was 4 months. The levels of xenoreactive antibodies (anti-Gal $\alpha(1,3) \mathrm{Gal}$ IgM) in these animals were generally higher than those of baboons that had not had a heart transplantation, and the levels of these antibodies did not differ between the control animals and the immunodepleted group. Other studies have been done in our laboratory using baboons that had not been exposed to swine organs, and the results in these animals were similar to results in the control baboons. These findings suggest that although xenoreactive antibody may play a role in swine-to-primate pulmonary xenotransplantation, it alone is not the determining factor in the course of rejection of these organs.

Swine-to-primate hyperacute rejection has been averted for some time in the heart and kidney ${ }^{11,12}$ and has now been overcome in pulmonary xenografts in this study. However, several additional barriers remain to be conquered before clinical xenotransplantation can be achieved. The next such barrier is delayed xenograft rejection. ${ }^{13}$ Whereas hyperacute rejection occurs within minutes to hours, delayed xenograft rejection takes place over days to weeks. ${ }^{13,14}$ The primary causative factor in delayed xenograft rejection of swine hearts transplanted into baboons appears to be the deposition of xenoreactive antibody on the endothelial surface. ${ }^{12}$ Several studies have demonstrated that there is minimal deposition of xenoreactive antibodies on the endothelium of swine-to-primate pulmonary xenografts. ${ }^{7,15}$ The lack of accumulation of xenoreactive antibodies on the pulmonary endothelium suggests that swine-to-primate pulmonary xenografts may be resistant to delayed xenograft rejection. ${ }^{15}$
The potential impact of pulmonary xenotransplantation cannot be overestimated. Patients who currently have pulmonary dysfunction would be able to receive a young organ, free of disease, chosen for an ideal size match, and at an opportune time. Furthermore, the use of animals for organ transplantation opens an avenue for the genetic engineering of donors, in which it may be possible to optimize the physiologic, biochemical, and immunologic needs of the recipient.

\section{REFERENCES}

1. Owens CE, Evans RW, Acher NL. Estimates of organ specific donor availability for the United States. Transplantation Proc 1993;25:1541-42.

2. The Registry of the International Society for Heart and Lung Transplantation. Tenth official report-1993. J Heart Lung Transplant 1993;12:541.

3. Jurman MJ, Haverich A, Demertzis S, et al. Extracorporeal membrane oxygenation (ECMO): extended indications for artificial support of both heart and lungs. Int J Artif Organs 1991; 14:771.

4. Bryant L, Eiseman B, Avery M. Studies of the porcine lung as an oxygenator for human blood. J Thorac Cardiovasc Surg 1968;55:255-63.

5. Campbell G, Crisp N, Brown E. Total cardiac by-pass in humans utilizing a pump and heterologous lung oxygenator (dog lungs). Surgery 1956:40:364-71.

6. Pierson R III, Kaspar-Konig W, Tew DN, Young VK, Braidley PC, White DJ, et al. Profound pulmonary hypertension characteristic of pig lung rejection by human blood is mediated by xenoreactive antibody independent of complement. Transplant Proc 1995;27:274.

7. Daggett CW, Yeatman M, Lodge AJ, Chen EP, Van Trigt P, Byrne GW, et al. Genetically engineered swine lungs resist injury in a human plasma perfusion model. J Thorac Cardiovasc Surg 1997;113:390-8.

8. Daggett CW, Yeatman M, Lodge AJ, Srinivasan M, Chen EP, Byrne GW, et al. Transgenic swine-to-primate pulmonary xenotransplantation. Surg Forum 1996;47:413-5.

9. Platt JL, Turman MA, Noreen HJ, et al. An ELISA assay for xenoreactive natural antibodies. Transplantation 1990;49: 1000.

10. Kent JF, Fife EH. Precise standardization of reagents for complement fixation. Am J Trop Med 1963;12:103.

11. Rosenberg JC, Broersma RJ, Bullemer G, et al. Relationship of platelets, blood coagulation, and fibrinolysis to hyperacute rejection of renal xenografts. Transplantation 1969;8:152-61.

12. Rosenberg JC, Hawkins E, Rector F. Mechanisms of immunological injury during antibody-mediated hyperacute rejection of renal hetergrafts. Transplantation 1971;11:151-7.

13. McCurry KD, Kooyman DL, Alvarado CW, Cotterell A, Martin M, Logan J, et al. Human complement regulatory proteins protect swine-to-primate cardiac xenografts from humoral injury. Nature Med 1995;1:423-7.

14. Hoopes CW, Platt JL. Molecular strategies for clinical xenotransplantation in cardiothoracic surgery. Sem Thorac Cardiothorac Surg 1996;8:156-74.

15. Kaplon RJ, Platt JL, Kwiatkowski PA, Edwards NM, Xu H, Shah AS, et al. Absence of hyperacute rejection in pig-to- 
primate orthotopic pulmonary xenografts. Transplantation 1995;59:410-6.

\section{Discussion}

Dr. Keith Reemtsma (New York, N.Y.). Congratulations on this superb work. Particularly important, I believe, are your excellent physiologic studies on gas exchange and blood flow. What is your next step?

Dr. Daggett. Thank you very much. Two steps need to be taken next. The first one is a survival study, which we are currently working on. The long-term survival of the pulmonary xenograft has yet to be determined. Also, more work needs to be done on the fundamental process of hyperacute rejection so that specific aims can be detailed to the prevention of this process.

Dr. Axel Haverich (Hannover, Germany). Did you mention the presence or absence of preformed xenoreactive antibodies in your baboon population?

Dr. Daggett. The average level of preformed xenoreactive antibody, as we determined it by measuring the anti-Gal $\alpha(1,3) \mathrm{Gal}$ IgM levels, was $31.7 \%$. After depletion, we achieved an $88.1 \%$ depletion of those antibodies with this procedure.
Dr. Larry R. Kaiser (Philadelphia, Pa.). Have you looked at other ways of absorbing the xenoantibodies short of perfusing the swine lung? Are there other artificial means of doing that?

Dr. Daggett. That is an excellent question. We have used a specific column for the depletion of all antibodies within the baboon. Our preliminary studies indicated that this was not as effective as swine lung perfusion before transplantation.

Dr. Kaiser. One baboon in your experimental group did not tolerate the right hilum crossclamping. To what do you attribute that failure?

Dr. Daggett. Although the animals tolerated the crossclamping, there was a significant increase in the pulmonary arterial pressure after crossclamping. The animal that did not tolerate crossclamping had right ventricular failure, and therefore the crossclamp was released. This animal was not included in the respiratory physiology data but was included in the pulmonary blood flow data.

Dr. Nasser K. Altorki (New York, N.Y.). Did you alter the temperature of the perfusate at all?

Dr. Daggett. The perfusate was maintained at $37^{\circ} \mathrm{C}$ with a heat exchanger in the circuit. 